\title{
CETP inhibitors and cardiovascular disease: Time to think
}

\section{again [version 1; peer review: 2 approved]}

\section{Norman E Miller}

Magdalen College, University of Oxford, Oxford, OX1 4AU, UK

\author{
V1 First published: 10 Jun 2014, 3:124 \\ https://doi.org/10.12688/f1000research.4396.1 \\ Latest published: 10 Jun 2014, 3:124 \\ https://doi.org/10.12688/f1000research.4396.1
}

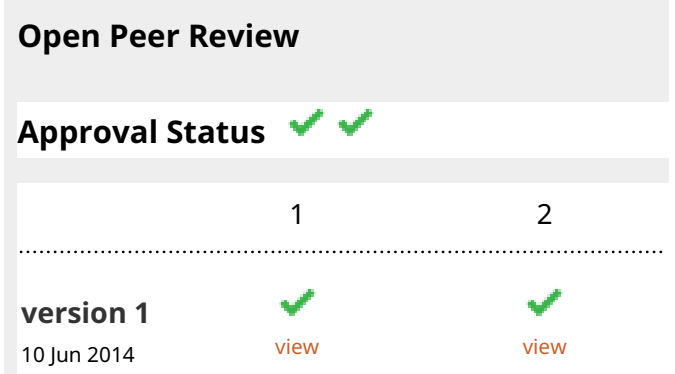

1. Gerald F. Watts, University of Western

Australia, Crawley, WA, Australia

2. Cesare Sirtori, University of Milan, Milan,

Italy

Any reports and responses or comments on the article can be found at the end of the article. 
Corresponding author: Norman E Miller (norman.miller@magd.ox.ac.uk)

Competing interests: No competing interests were disclosed.

Grant information: The author(s) declared that no grants were involved in supporting this work.

Copyright: $\odot 2014$ Miller NE. This is an open access article distributed under the terms of the Creative Commons Attribution License, which permits unrestricted use, distribution, and reproduction in any medium, provided the original work is properly cited. Data associated with the article are available under the terms of the Creative Commons Zero "No rights reserved" data waiver (CC0 1.0 Public domain dedication).

How to cite this article: Miller NE. CETP inhibitors and cardiovascular disease: Time to think again [version 1; peer review: 2 approved] F1000Research 2014, 3:124 https://doi.org/10.12688/f1000research.4396.1

First published: 10 Jun 2014, 3:124 https://doi.org/10.12688/f1000research.4396.1 


\section{Background}

Cholesteryl ester transfer protein (CETP) is a hydrophobic glycoprotein in plasma that catalyzes the transfer of neutral lipids between plasma lipoproteins ${ }^{1}$. The notion that inhibition of CETP activity might prevent coronary heart disease (CHD) was based on the knowledge that it both reduces plasma low-density lipoprotein (LDL) cholesterol concentration, and raises high-density lipoprotein (HDL) cholesterol. While there is abundant evidence that reduction of LDL cholesterol is likely to be beneficial, the effect of CETP inhibition on the function of HDL in reverse cholesterol transport from tissues (RCT) has been uncertain.

In 1996 Fielding and $\mathrm{Havel}^{2}$ argued against a hasty commitment to CETP inhibitors, drawing attention to evidence that CETP participates in the remodelling of the cholesteryl ester-rich $\alpha$-HDLs that generates the small lipid-poor pre $\beta$-HDLs that are the primary acceptors of cholesterol via the ABCA1 transporters in cell membranes ${ }^{3}$. The rise in HDL cholesterol might be misleading, they argued, and reflect only retention of cholesteryl esters in the particles, while the uptake of cholesterol from arterial cells is diminished. Nevertheless, encouraged by reports that CETP gene transfer induced atherosclerosis in mice ${ }^{4}$ and that CETP inhibition prevented atherosclerosis in rabbits ${ }^{5-7}$, drug discovery programmes made rapid progress.

The case for inhibition was weakened when later studies of CETP transgenic mice contradicted the earlier findings ${ }^{8,9}$, and the incidence of CHD was not found to be significantly reduced in familial CETP deficiency ${ }^{10}$. Studies of the relation of CHD to single nucleotide polymorphisms (SNPs) of the CETP gene yielded disparate outcomes, which were not resolved by meta-analyses ${ }^{11-13}$. When Dullaart et al. ${ }^{13}$ meta-analyzed data on the Taq1B SNP (rs708272) from populationbased and high-risk groups separately, the odds ratio for cardiovascular disease (CVD) in homozygotes for the $B 2$ allele (who have low CETP activity) was 0.84 in the high-risk subjects, but 1.45 in the population-based samples. This suggested that low CETP activity actually increases CVD risk, and that its seeming protective effect in some studies may have resulted from selection towards a lower frequency of the $B 2$ allele in high-risk groups.

The dual uncertainties over the effect of CETP inhibition on HDL function and whether it is more likely to reduce or increase CVD in humans were unresolved when the first Phase 3 study (ILLUMINATE; NCT00134264) of a member of this class of drugs (torcetrapib) was started in July $2004^{14}$. In June 2007, the trial was terminated after it had become clear that the treatment had increased the incidence of the primary CVD endpoint. The authors concluded that this was probably owing to an unanticipated rise in blood pressure, but three findings challenged this interpretation. CHD mortality was related inversely to increment in blood pressure; the incidence of stroke was not raised by treatment; and non-cardiovascular mortality was increased. A Phase 3 trial of dalcetrapib (Dal-OUTCOMES; NCT00658515), a less potent inhibitor with little or no effect on blood pressure, was started in April 2008. In November 2012, this study was also terminated when it became evident that the outcome was not going to be positive ${ }^{15}$.

In the same year that ILLUMINATE enrolled its first participant, the first prospective data on plasma CETP as a risk factor for clinical
CVD events were also published. Boekholdt et al. ${ }^{16}$ had found that CETP concentration, with which CETP activity is linearly related ${ }^{17}$, did not differ significantly between 1,400 controls and 735 subjects who had developed myocardial infarction (MI) during six years of follow-up, although a positive association was seen on post hoc analysis in subjects with plasma triglycerides exceeding the median of $1.7 \mathrm{mmol} / \mathrm{l}$.

Recent findings on plasma CETP as a CVD risk factor The first prospective observational cohort study of plasma CETP activity or concentration as a risk factor for clinical CVD events did not appear until July 2006, two years after ILLUMINATE had started. Since then five further similar studies have been published. All six studies found CVD incidence to be related inversely to plasma CETP $^{18-23}$. The designs and results of these studies are summarised in Table 1. Cohorts ranged from 1,002 to 3,256 subjects, and follow-up periods from two to 15 years (weighted average, 7.6 years). One study followed men and women separately ${ }^{23}$. Three were of first CVD events in healthy subjects ${ }^{18,19,23}$; two were of second events in subjects with an existing history of $\mathrm{CHD}^{20,21}$; and in one study primary and secondary events were pooled ${ }^{22}$. In two studies that looked at mortality in addition to CVD morbidity ${ }^{21,22}$ this was also negatively associated with CETP. Results in subjects taking pravastatin or atorvastatin ${ }^{18,20}$ mirrored those in other subjects. The suggestion in the earlier case-control study ${ }^{16}$ that subjects with raised triglycerides might differ from others was not confirmed.

\section{Recent genome-wide analyses of CETP alleles and CVD} The CETP gene has been mapped to locus $16 \mathrm{q} 21$. It spans about $25 \mathrm{~kb}$, and consists of 16 exons and 15 introns. In the absence of a clear picture from candidate gene studies of the association of SNPs with CVD, two genome-wide analyses have recently been published, whose results appeared to conflict with those of the observational epidemiology. In a study of more than 350,000 SNPs in 18,245 women followed for 10 years, Ridker et $a l .{ }^{24}$ observed that three SNPs in or around the CETP gene (rs708272, rs4329913, rs7202364) were associated with increased HDL cholesterol and a reduced incidence of MI. A subsequent Mendelian randomization analysis found a single SNP of CETP (rs3764261) to be associated with raised HDL cholesterol and an apparent four per cent reduction in the incidence of $\mathrm{MI}^{25}$.

\section{Reconciling the observational epidemiology and genome-wide analyses}

The reliability of prospective observational epidemiology for the identification of causal effects in complex diseases has been in the spotlight of late, after some results were not confirmed in randomized clinical trials. Could the results of the recent observational studies of CETP be another instance of confounding or reverse causation? Confounding seems unlikely as multivariate analyses found the relation between CVD events and CETP concentration or activity to be independent of age, gender, hypertension, body mass index, plasma triglycerides, adiponectin, diabetes, and smoking habit ${ }^{18-23}$. Reverse causation due to a reduction of plasma CETP in response to vascular inflammation also seems improbable, as the association persisted after adjustment for plasma homocysteine, interleukin-6 and C-reactive protein concentrations ${ }^{22,23}$.

As discussed by several authors ${ }^{26-28}$, genome-wide analyses are also not without their limitations, and several aspects of the two studies 


\section{Table 1. Prospective observational cohort studies of CVD risk and plasma CETP concentration or activity.}

\begin{tabular}{|c|c|c|}
\hline Study & Design & Results \\
\hline Marschang $2006^{18}$ & $\begin{array}{l}1002 \text { subjects (mean age, } 65 \text { yr; } 44 \% \\
\text { female) free of CVD and taking pravastatin } \\
\text { were followed for two years, during which } \\
100 \text { suffered a CVD event. }\end{array}$ & $\begin{array}{l}\text { Significantly more } C V D \text { events in the bottom quartile of CETP conc } \\
\text { than in the top quartile }(O R 3.2, P=0.001) \text {. The association remained } \\
\text { significant }(P=0.001) \text { after adjustment for age, sex, lipids and } \\
\text { other risk factors. Similar result observed for cardiac events alone } \\
(P=0.009) \text {. }\end{array}$ \\
\hline $\begin{array}{l}\text { Vasan } 2009^{19} \\
\text { Framingham Heart } \\
\text { Study }\end{array}$ & $\begin{array}{l}1978 \text { subjects free of CVD (mean age, } 51 \mathrm{yr} \text {, } \\
54 \% \text { female) were followed for } 15 \text { years, } \\
\text { during which } 320 \text { suffered a CVD event. }\end{array}$ & $\begin{array}{l}\text { CVD incidence was negatively associated with CETP activity } \\
\text { (P=0.004) after adjustment for age, sex and standard risk factors. } \\
\text { CETP activity } \geq \text { median was associated with a risk reduction of } 30 \% \text {. }\end{array}$ \\
\hline $\begin{array}{l}\text { Khera } 2010^{20} \\
\text { PROVE IT-TIMI } 22 \\
\text { Study }\end{array}$ & $\begin{array}{l}3218 \text { subjects (mean age, } 58 \text { yr; } 21 \% \\
\text { female) with clinical CHD taking either } \\
\text { atorvastatin or pravastatin were followed } \\
\text { for two years, during which } 150 \text { suffered a } \\
\text { recurrent AMI or CHD death. }\end{array}$ & $\begin{array}{l}\text { CETP conc was negatively associated with } C H D \text { risk in unadjusted } \\
\text { data (HR per SD increase } 0.77, P=0.005) \text { and after adjustment for } \\
\text { age, sex and other risk factors }(0.81, P=0.027) \text {. In subjects whose } \\
\text { LDL was below the median, CETP conc above the median was } \\
\text { associated with a HR of } 0.52(P=0.02) \text {. }\end{array}$ \\
\hline $\begin{array}{l}\text { Duwensee } 2010^{21} \\
\text { KAROLA Study }\end{array}$ & $\begin{array}{l}1132 \text { subjects with clinical CHD (mean age } \\
59 \text { yr, } 15 \% \text { female, } 18 \% \text { diabetics) were } \\
\text { followed for } 8 \text { yr, during which there were } \\
150 \text { cases of fatal or non-fatal CVD, and } \\
119 \text { deaths. }\end{array}$ & $\begin{array}{l}\text { With or without adjustment for sex, age and standard risk factors, HR } \\
\text { for a new CVD event was negatively associated with CETP conc. } \\
\text { Relative to subjects with CETP above the median, those below it had } \\
\text { a HR for CVD of } 1.84(P<0.02) \text {, and for total mortality of } 1.57(P=0.04) \text {. }\end{array}$ \\
\hline $\begin{array}{l}\text { Ritsch } 2010^{22} \\
\text { LURIC Study }\end{array}$ & $\begin{array}{l}3256 \text { subjects referred for coronary } \\
\text { angiography (mean age } 62 \text { yr, } 30 \% \\
\text { female), of whom } 2560 \text { had verified CAD, } \\
\text { were followed for a mean of eight years, } \\
\text { during which there were } 754 \text { total deaths, } \\
\text { and } 474 \text { deaths from CVD. }\end{array}$ & $\begin{array}{l}\text { CETP conc was lower in patients with CAD than in those without } \\
(P=0.002) \text {. Relative to the top CETP quartile, age- and sex-adjusted } \\
\text { HR for CVD death in the bottom quartile was } 1.38(P=0.02) \text {, and } \\
\text { that for total mortality was } 1.37(P=0.004) \text {. HRs were unaffected by } \\
\text { adjustment for other risk factors. }\end{array}$ \\
\hline $\begin{array}{l}\text { Robins } 2013^{23} \\
\text { Framingham } \\
\text { Offspring Study }\end{array}$ & $\begin{array}{l}2679 \text { subjects (mean age, } 58 \mathrm{yr}, 56 \% \\
\text { female) free of CVD were followed for a } \\
\text { mean of } 10.4 \text { yr, during which } 187 \text { suffered } \\
\text { a CVD event. }\end{array}$ & $\begin{array}{l}\text { In men CVD risk was associated negatively with CETP activity and } \\
\text { positively with PLTP activity. After adjustment for PLTP and other risk } \\
\text { factors, CVD remained negatively associated with CETP activity (HR } \\
0.64, P=0.026 \text { ). No significant associations in women. }\end{array}$ \\
\hline
\end{tabular}

Studies limited to coronary angiography without clinical endpoints are not included. AMI, acute myocardial infarction; BMI, body mass index; CAD, coronary artery disease; CHD, coronary heart disease; CVD, cardiovascular disease; HR, hazard ratio; OR, odds ratio; PLTP, phospholipid transfer protein.

warrant consideration. One is that there appears to have been no concordance between them in the alleles found to be associated with MI. Second, as data on plasma CETP were not available to either study, the relations with disease could have been owing to linkage with other genes that affect HDL and MI through independent mechanisms. The strongest association in the first study ${ }^{24}$ was with rs708272, the Taq1B SNP of CETP. This intronic polymorphism has no direct affect on CETP activity. Furthermore, the allele associated with low incidence of MI has also been found to be associated with a low prevalence of metabolic syndrome ${ }^{29}$, a potential confounder being itself a strong risk factor for CVD. The other two alleles were remote from the CETP gene, being in SLC12A3 and $N U P 93$, respectively a solute transporter gene and the gene for a nucleoporin. The relation of MI to rs3764261 described in the more recent genome-wide study was adjusted for age and sex, but not for other potential confounders ${ }^{25}$. Furthermore, the result has since been contradicted by a meta-analysis of data from 16,570 subjects $^{30}$, which found the $T$ allele of the same SNP to be associated with reduced effectiveness of statins in preventing $\mathrm{MI}$.

Papp et al. ${ }^{31}$ have recently addressed the issue of genetically determined low CETP activity by using mRNA allelic expression and splice isoform assays to identify genetic variants that affect plasma CETP concentration, and then examining their relation to incident MI. In studies of 94 human livers, a common alternatively spliced isoform lacking exon 9 prevented CETP secretion in a dominant-negative manner. Increased formation of this isoform was exclusively associated with two polymorphisms in high linkage disequilibrium: one in exon 9 of $C E T P$ ( $r 55883-C>T)$, which alters an exonic splicing enhancer sequence, and another in intron 8 (rs9930761-T>C), which changes a splicing branch point nucleotide. In the INVEST-GENES prospectively followed cohort, it was found that $\mathrm{rs} 5883 \mathrm{~T} / \mathrm{rs} 9930761 \mathrm{C}$ were associated with high incidence rates of $\mathrm{MI}$ and stroke $(\mathrm{P}=0.005)$ despite raised HDL cholesterol, strongly reinforcing the observational epidemiology.

\section{Recent studies of CETP, HDL function and reverse cholesterol transport}

While the epidemiologic landscape has thus evolved, laboratory research has strengthened the evidence that CETP plays an important role in RCT. Tanigawa et al. ${ }^{32}$ found that hepatic CETP gene transfer in mice stimulated the transport of cholesterol from peritoneal macrophages to the liver, followed by its elimination as bile acids. Tchoua et al..$^{33}$ independently confirmed this result, and showed that the effect was blocked when the animals were given torcetrapib. There is no accepted method for quantifying reverse cholesterol transport in vivo in humans, but three groups have recently reported that human plasma with high CETP activity had a greater capacity to promote cholesterol efflux from cultured cells than plasma with low activity ${ }^{34-36}$. Villard et al $^{34}$ showed further that addition of purified CETP increased both the pre $\beta$-HDL concentration in normal human plasma and its capacity to remove cholesterol 
from cultured cells, reproducing an earlier result obtained with plasma from a subject with familial CETP deficiency ${ }^{37}$. Thus, the confusion over the contribution of CETP to RCT appears to have been resolved, and the concerns expressed by Fielding and Havel almost 20 years ago substantiated.

\section{Perspective}

The history of the hypothesis that CETP inhibition will prevent atherosclerosis can be summarised thus. At the outset, our understanding of HDL biochemistry did not permit any predictions of its effect on RCT, but was sufficient to tell us that it might go either way. In the absence of information on the relation of CVD risk to CETP activity in humans, enthusiasm for the concept was fuelled by positive results in cholesterol-fed rabbits, which seemed to confirm that a rise in HDL cholesterol is a dependable biomarker of benefit. However, the first prospective cohort study of CETP as a CVD risk factor challenged this assumption. Since then, five further prospective observational studies have left no doubt that in populations CVD risk is related inversely to CETP activity. Confounding and reverse causation seem unlikely explanations. Although two genome-wide analyses appeared to have produced contrary evidence, for the reasons discussed they have not refuted the observational data. On the other hand, the latter have been reinforced by reports that subjects with functional CETP alleles that lower CETP secretion have an increased risk of MI. Thus, the weight of evidence has now shifted to the likelihood that CETP inhibition will have an adverse effect on CVD outcomes, not the beneficial effect that was hoped for. Recent laboratory studies on the impact of CETP activity on the cholesterol transport function of HDL have been consistent with this interpretation.

This interpretation does not conflict with the anti-atherogenic effect of CETP inhibition in rabbits. Apart from the obvious possibility of a species specific difference in cholesteryl ester dynamics, Shimoji et $a l .^{38}$ reported that dalcetrapib increases the synthesis rate of the major HDL protein (apo AI) in rabbits by 44 per cent, an effect that on its own would be expected to substantially reduce atherosclerosis ${ }^{39}$. By contrast, inhibition of CETP with torcetrapib had no effect on apo AI synthesis in humans ${ }^{40}$. It is also worth noting that probucol, which increases CETP activity ${ }^{41}$, also prevents atherosclerosis in rabbits despite lowering apo AI synthesis rate rit,42. $^{4}$.

Although the body of disquieting data has been growing for several years, there has been surprisingly little public discussion of the issue. The paper describing the outcome of ILLUMINATE ${ }^{14}$ made no reference to the results of Marschang et al. ${ }^{18}$ published the year before. Likewise, the report on Dal-OUTCOMES ${ }^{15}$ made no mention of any one of the six observational cohort studies listed in Table 1, all of which were already in print. The same is true of an article investigating the harm caused by torcetrapib in ILLUMINATE ${ }^{43}$, and of several recent review articles ${ }^{44-48}$.

\section{Implications}

These recent developments have significant implications. First, they are consistent with other evidence that plasma HDL cholesterol concentration is not a reliable marker of the efficiency of $\mathrm{RCT}^{49,50}$. Second, they show that clinical trials of CETP inhibitors do not test the HDL hypothesis in the manner originally envisaged. Third, they raise a pressing issue in the context of two Phase 3 studies of second generation CETP inhibitors currently in progress. ACCELERATE (NCT01687998) $^{51}$, which began in 2012 and is expected to finish in 2016, has enrolled about 12,000 patients with high-risk CVD to assess the efficacy of evacetrapib ${ }^{52}$ in preventing CVD events. REVEAL (NCT01252953) ${ }^{53}$, commenced in 2011 and expected to be completed in 2017, has enrolled 30,624 patients for a similar study of anacetrapib ${ }^{54}$. In both studies, the patients in each arm are being given a statin to control LDL concentration prior to randomization.

Anacetrapib is the most potent CETP inhibitor to date, and was found in DEFINE (NCT00685776) ${ }^{54}$ to lower LDL cholesterol by 50 per cent compared with the 25 per cent achieved with torcetrapib $^{14}$. It is theoretically possible that this greater impact on LDL will override any adverse effect on HDL function, but it is equally possible that its greater impact on HDL cholesterol (140 per cent increase compared with 70 per cent) reflects such an extreme disturbance of HDL metabolism that its consequences will predominate. Neither the prospective epidemiology nor studies of familial CETP deficiency have provided evidence of a fall in CVD risk at extremely low activities. Although DEFINE recorded no increase in CVD in patients given anacetrapib, the authors noted that the study was too small to provide reliable information on clinical events ${ }^{54}$.

\section{Conclusion}

Given that the tide of evidence has turned so strongly against CETP inhibition in recent years, the question must be asked of whether it is now ethical to continue with the two Phase 3 trials in progress. A clinical trial is considered to be ethical only if it has a sound scientific basis and a favourable risk-benefit balance ${ }^{55}$. The two trials in question no longer satisfy either requirement, as there is clearly a strong possibility that the drugs will have exactly the opposite effect on CVD to that intended. Some might argue that there is no cause for concern, as morbidity and mortality are being regularly reviewed by data monitoring committees. However, such committees can intervene only when pre-specified statistical criteria have been met, by which time many participants may have suffered harm.

Carrying on and hoping for the best is not an acceptable option. An independent review is urgently needed to determine if the trials should be discontinued.

\section{Competing interests}

No competing interests were disclosed.

\section{Grant information}

The author(s) declared that no grants were involved in supporting this work. 
1. Fielding CJ, Fielding PE: Molecular physiology of reverse cholesterol transport. J Lipid Res. 1995; 36(2): 211-28.

PubMed Ab

2. Fielding CJ, Havel RJ: Cholesteryl ester transfer protein: friend or foe? J Clin Invest. 1996; 97(12): 2687-8.

PubMed Abstract | Publisher Full Text | Free Full Text

3. Hennessy LK, Kunitake ST, Kane JP: Apolipoprotein A-I-containing lipoproteins, with or without apolipoprotein A-II, as progenitors of pre-beta high density lipoprotein particles. Biochemistry. 1993; 32(22): 5759-65.

PubMed Abstract | Publisher Full Text

4. Marotti KR, Castle CK, Boyle TP, et al:: Severe atherosclerosis in transgenic mice expressing simian cholesteryl ester transfer protein. Nature. 1993 364(6432): 73-5.

PubMed Abstract | Publisher Full Text

5. Okamoto $\mathrm{H}$, Yonemori $\mathrm{F}$, Wakitani $\mathrm{K}$, et al: $\mathrm{A}$ cholesteryl ester transfer protein inhibitor attenuates atherosclerosis in rabbits. Nature. 2000; 406(6792): 203-7. PubMed Abstract | Publisher Full Text

6. Sugano O, Makino N, Sawada S, et al.: Effect of antisense oligonucleotides against cholesteryl transfer protein on the development of atherosclerosis in cholesterol-fed rabbits. J Biol Chem. 1998; 273(9): 5033-6.

PubMed Abstract | Publisher Full Text

7. Ritterhaus CW, Miller DP, Thomas LJ, et al:: Vaccine-induced antibodies inhibit CETP activity in vivo and reduce aortic lesions in a rabbit model of atherosclerosis. Arterioscler Thromb Vasc Biol. 2000; 20(9): 2106-12. PubMed Abstract | Publisher Full Text

8. Hayek T, Masucci-Magoulas L, Jiang X, et al.: Decreased early atherosclerotic lesions in hypertriglyceridemic mice expressing cholesteryl ester transfer protein transgene. J Clin Invest. 1995; 96(4): 2071-4. PubMed Abstract | Publisher Full Text | Free Full Text

9. Föger B, Chase M, Amar MJ, et al.: Cholesteryl ester transfer protein corrects dysfunctional high density lipoproteins and reduces aortic atherosclerosis in lecithin cholesterol acyltransferase transgenic mice. J Biol Chem. 1999; 274(52): 36912-20.

PubMed Abstract | Publisher Full Text

10. Curb JD, Abbott RD, Rodriguez BL, et al:: A prospective study of HDL-C and cholesteryl ester transfer protein gene mutations and the risk of coronary heart disease in the elderly. $J$ Lipid Res. 2004; 45(5): 948-53. PubMed Abstract | Publisher Full Text

11. Thompson A, Di Angelantonio E, Sarwar N, et al:: Association of cholesteryl ester transfer protein genotypes with CETP mass and activity, lipid levels, anc coronary risk. JAMA. 2008; 299(23): 2777-88.

PubMed Abstract | Publisher Full Text

12. LiYY, Wu XY, Xu J, et al:: Apo A5 -1131T/C, FgB -455G/A, -148C/T, and CETP TaqIB gene polymorphisms and coronary artery disease in the Chinese population: a meta-analysis of 15,055 subjects. Mol Biol Rep. 2013; 40(2): 1997-2014. PubMed Abstract | Publisher Full Text

13. Dullaart RP, Sluiter WJ: Common variation in the CETP gene and the implications for cardiovascular disease and its treatment: an updated analysis. Pharmacogenomics. 2008; 9(6): 747-63. PubMed Abstract | Publisher Full Tex

14. Barter PJ, Caulfield M, Eriksson M, et al.: Effects of torcetrapib in patients at high risk for coronary events. N Engl J Med. 2007; 357(21): 2109-22. PubMed Abstract | Publisher Full Tex

15. Schwartz GG, Olsson AG, Abt M, et al.: Effects of dalcetrapib in patients with a recent acute coronary syndrome. N Engl J Med. 2012; 367(22): 2089-99. PubMed Abstract | Publisher Full Text

16. Boekholdt SM, Kuivenhoven JA, Wareham NJ, et al.: Plasma levels of cholestery ester transfer protein and the risk of future coronary artery disease in apparently healthy men and women: the Prospective EPIC (European Prospective Investigation into Cancer and Nutrition)-Norfolk population study. Circulation. 2004; 110(11): 1418-23. PubMed Abstract | Publisher Full Text

17. Ritsch A, Auer B, Foger B, et al.: Polyclonal antibody-based immunoradiometric assay for quantification of cholesteryl ester transfer protein. J Lipid Res. 1993; 34(4): 673-79.

PubMed Abstract

18. Marschang P, Sandhofer A, Ritsch A, et al.: Plasma cholesteryl ester transfer protein concentrations predict cardiovascular events in patients with coronar artery disease treated with pravastatin. J Intern Med. 2006; 260(2): 151-9. PubMed Abstract | Publisher Full Text

19. Vasan RS, Pencina MJ, Robins SJ, et al:: Association of circulating cholesteryl ester transfer protein activity with incidence of cardiovascular disease in the community. Circulation. 2009; 120(24): 2414-20. PubMed Abstract | Publisher Full Text | Free Full Text

20. Khera AV, Wolfe ML, Cannon CP, et al.: On-statin cholesteryl ester transfer protein mass and risk of recurrent coronary events (from the pravastatin or atorvastatin evaluation and infection therapy-thrombolysis in myocardia infarction 22 [PROVE IT-TIMI 22] study). Am J Cardiol. 2010; 106(4): 451-6. PubMed Abstract | Publisher Full Tex

21. Duwensee K, Breitling LP, Tancevski I, et al.: Cholesteryl ester transfer protein in patients with coronary heart disease. Eur J Clin Invest. 2010; 40(7): 616-22. PubMed Abstract | Publisher Full Text

22. Ritsch A, Scharnagl $\mathrm{H}$, Eller $\mathrm{P}$, et al:: Cholesteryl ester transfer protein and mortality in patients undergoing coronary angiography: the Ludwigshafen Risk and Cardiovascular Health study. Circulation. 2010; 121(3): 366-74. PubMed Abstract | Publisher Full Text | Free Full Text

23. Robins SJ, Lyass A, Brocia RW, et al:: Plasma lipid transfer proteins and cardiovascular disease. The Framingham Heart Study. Atherosclerosis. 2013; 228(1): $230-6$

PubMed Abstract | Publisher Full Text | Free Full Text

24. Ridker PM, Paré G, Parker AN, et al.: Polymorphism of the CETP gene region, HDL cholesterol, and risk of future myocardial infarction: Genomewide analysis among 18245 healthy women from the Women's Genome Health Study. Circ Cardiovasc Genet. 2009; 2(1): 26-33.

PubMed Abstract | Publisher Full Text | Free Full Text

25. Voight BF, Peloso GM, Ortho-Melander M, et al:: Plasma HDL cholesterol and risk of myocardial infarction: a mendelian randomisation study. Lancet. 2012; 380(9841): 572-80.

PubMed Abstract | Publisher Full Text | Free Full Text

26. Smith GD, Ebrahim S: Mendelian randomization: prospects, potentials, and limitations. Int J Epidemiol. 2004; 33(1): 30-42.

PubMed Abstract | Publisher Full Text

27. Sleiman PM, Grant SF: Mendelian randomization in the era of genomewide association studies. Clin Chem. 2010; 56(5): 5723-8. PubMed Abstract | Publisher Full Text

28. Barsh GS, Copenhaver GP, Gibson G, et al.: Guidelines for genome-wide association studies. PLoS Genet. 2012; 8(7): e1002812. PubMed Abstract | Publisher Full Text | Free Full Text

29. Sandhofer A, Tatarczyk T, Laimer M, et al.: The Taq1B-variant in the cholesteryl ester-transfer protein gene and the risk of metabolic syndrome. Obesity (Silver Spring). 2008; 16(4): 919-22.

PubMed Abstract | Publisher Full Text

30. Leusink M, Onland-Moret NC, Asselbergs FW, et al.: Cholesteryl ester transfer protein polymorphisms, statin use and their impact on cholesterol levels and cardiovascular events. Clin Pharmacol Ther. 2014; 95(3): 314-20.

PubMed Abstract | Publisher Full Text

31. Papp AC, Pinsonneault JK, Wang W, et al.: Cholesteryl Ester Transfer Protein (CETP) polymorphisms affect mRNA splicing, HDL levels, and sex-dependent cardiovascular risk. PLoS One. 2012; 7(3): e31930.

PubMed Abstract | Publisher Full Text |Free Full Text

32. Tanigawa H, Billheimer JT, Tohyama J, et al:: Expression of cholesteryl ester transfer protein in mice promotes macrophage reverse cholesterol transport Circulation. 2007; 116(11): 1267-73.

PubMed Abstract | Publisher Full Tex

33. Tchoua U, D'Souza W, Mukhamedova N, et al:: The effect of cholesteryl ester transfer protein overexpression and inhibition on reverse cholesterol transport. Cardiovasc Res. 2008; 77(4): 732-9.

PubMed Abstract | Publisher Full Text

34. Villard EF, El Khoury P, Duchene E, et al:: Elevated CETP activity improves plasma cholesterol efflux capacity from human macrophages in women. Arterioscler Thromb Vasc Biol. 2013; 32(10): 2341-9. PubMed Abstract | Publisher Full Text

35. Borggreve SE, de Vries R, Dallinga-Thie GM, et al:: The ability of plasma to stimulate fibroblast cholesterol efflux is associated with the $-629 \mathrm{C}-->\mathrm{A}$ cholesteryl ester transfer protein promoter polymorphism: role of lecithin: cholesterol acyltransferase activity. Biochim Biophys Acta. 2008; 1781(1-2): $10-5$. PubMed Abstract | Publisher Full Text

36. Scharnag $\mathrm{IH}$, Heuschneider $\mathrm{C}$, Sailer $\mathrm{S}$, et al.: Decreased cholesterol efflux capacity in patients with low cholesteryl ester transfer protein plasma levels. Eur J Clin Invest. 2014; 44(4): 395-401.

PubMed Abstract | Publisher Full Text

37. Yamashita S, Ishigami M, Arai T, et al.: Very high density lipoproteins induced by plasma cholesteryl ester transfer protein (CETP) have a potent antiatherogenic function. Ann NY Acad Sci. 1995; 748: 606-8.

PubMed Abstract | Publisher Full Text

38. Shimoji E, Zhang B, Fan P, et al.: Inhibition of cholesteryl ester transfer protein increases serum apolipoprotein (apo) A-I levels by increasing the synthesis of apo A-I in rabbits. Atherosclerosis. 2004; 172(2): 247-57.

PubMed Abstract | Publisher Full Text

39. Duverger N, Kruth $\mathrm{H}$, Emmanuel F, et al.: Inhibition of atherosclerosis development in cholesterol-fed human apolipoprotein A-I-transgenic rabbits. Circulation. 1996; 15(4): 94: 713-7. PubMed Abstract | Publisher Full Tex

40. Brousseau ME, Diffenderfer MR, Millar JS, et al: Effects of cholesteryl ester transfer protein inhibition on high-density lipoprotein subspecies, apolipoprotein A-I metabolism, and fecal sterol excretion. Arterioscler Thromb Vasc Biol. 2005; 25(5): 1057-64.

PubMed Abstract | Publisher Full Text | Free Full Text

41. Oshima R, Ikeda T, Watanabe K, et al.: Probucol treatment attenuates the aortic 
atherosclerosis in Watanabe heritable hyperlipidemic rabbits. Atherosclerosis. 1998; 137(1): 13-22.

PubMed Abstract | Publisher Full Text

42. Ying H, Saku K, Harada R, et al.: Putative mechanisms of action of probucol on high-density lipoprotein apolipoprotein A-I and its isoproteins kinetics in rabbits. Biochim Biophys Acta. 1990; 1047(3): 247-54. PubMed Abstract | Publisher Full Text

43. Barter PJ, Rye KA, Beltangady MC, et al:: Relationship between atorvastatin dose and the harm caused by torcetrapib. J Lipid Res. 2012; 53(11): 2436-42. PubMed Abstract | Publisher Full Text | Free Full Text

44. Barter PJ, Rye KA: Cholesteryl ester transfer protein inhibition as a strategy to reduce cardiovascular risk. J Lipid Res. 2012; 53(9): 1755-66.

PubMed Abstract | Publisher Full Text | Free Full Text

45. Durrington PN: Cholesteryl ester transfer protein (CETP) inhibitors. Br J Cardiol. 2012; 19: 126-33. Publishr Full Text

46. Hewing B, Fisher EA: Rationale for cholesteryl ester transfer protein inhibitors. Curr Opin Lipidol. 2012; 23(4): 372-6.

PubMed Abstract | Publisher Full Text | Free Full Text

47. Shinkai $\mathrm{H}$ : Cholesteryl ester transfer protein inhibitors and their potential for the treatment of cardiovascular diseases. Vasc Health Risk Manag. 2012; 8: 323-31. PubMed Abstract | Publisher Full Text | Free Full Text

48. Miyares MA, Davis K: Patient considerations and clinical impact of cholesteryl ester transfer protein inhibitors in the management of dydlipidaemia: focus on anacetrapib. Vasc Health Risk Manag. 2012; 8: 483-93 PubMed Abstract | Publisher Full Text | Free Full Text

49. deGoma EM, Rader DJ: High-density lipoprotein particle number: a better measure to quantify high-density lipoprotein? J Am Coll Cardiol. 2012; 60(8): 517-20. PubMed Abstract | Publisher Full Text

50. Kingwell BA, Chapman MJ, Kontush A, et al.: HDL-targeted therapies: progress, failures and future. Nat Rev Drug Discov. 2014; 13(6): 445-64.

PubMed Abstract | Publisher Full Text

51. A study of evacetrapib in high risk vascular disease.

Reference Source

52. Nicholls SJ, Brewer HB, Kastelein JJ, et al.: Effects of the CETP inhibitor evacetrapib administered as monotherapy or in combination with statins on HDL and LDL cholesterol: a randomized controlled trial. JAMA. 2011; 306(19): 2099-109. PubMed Abstract | Publisher Full Text

53. Randomized evaluation of the effects of anacetrapib through lipid-modification Reference Source

54. Cannon CP, Shah S, Dansky HM, et al: Safety of anacetrapib in patients with or at high risk for coronary heart disease. N Engl J Med. 2010; 363(25): 2406-15. PubMed Abstract | Publisher Full Text

55. Karlberg JPE, Speers MA: Reviewing clinical trials: A guide for ethics committees. 2010

Reference Source 


\section{Open Peer Review}

\section{Current Peer Review Status:}

\section{Version 1}

Reviewer Report 29 July 2014

https://doi.org/10.5256/f1000research.4705.r5614

(C) 2014 Sirtori C. This is an open access peer review report distributed under the terms of the Creative Commons Attribution License, which permits unrestricted use, distribution, and reproduction in any medium, provided the original work is properly cited.

\section{Cesare Sirtori}

Department of Pharmacological Sciences, University of Milan, Milan, Italy

This paper by Miller attempts to elucidate once and for all the present role of CETP and CETP antagonists in coronary prevention. The message is clear and well written. I do have a question on the structure of the paper however: while the background of CETP from the earlier papers by Havel is clear and well written, I question the idea of separating this from the very informative Table 1 which collates two separate pieces of information and is otherwise unclear.

Also, as the current trend is to evaluate genomic analysis, in particular by Mendelian randomization, this could indicate that HDL is not a genetic risk component. This should be given special emphasis, since the Mendelian randomization analysis was focused on LIPC (just one determinant of HDL levels) whereas the author points out that SNPS of CETP are also probably involved. However he gives no explanation of the mechanism of these SNPs, which are apparently associated with raised $\mathrm{HDL}$ and also with reduced incidence of MI.

In my view, the major focus of this paper should be on drugs, especially as drugs are still used to antagonize CETP in clinical trials. In the studies on torcetrapib it was noted (Nicholls et al, Circulation 2008) that individuals with the highest post-treatment HDL-cholesterol are apparently protected from coronary disease. Does this make sense? After all if HDL is traveling through the blood in very large amounts without going back to the artery this could provide some potential protection, although this should be evaluated with more rigor. A final note on the studies with torcetrapib is the incremental elevation of blood pressure. The rise of blood pressure was of such little entity (at most $5 \mathrm{mmHg}$ ) that just posting these data in a risk score (Framingham or other) allowed one to conclude that this influences risk minimally and does modify the enormous change in risk consequent to the HDL rise elicited by the CETP inhibitor (Sirtori, Mombelli, Clin. Chem, 2010).

In regards to the rabbit studies: this started with the Okamoto paper in Nature (2000), which had one serious problem; the control group only had a final cholesterol of $129 \mathrm{mg} / \mathrm{dl}$. Thus, in my view, the apparent advantage of giving JT -705 (dalcetrapib) makes no sense. A much better conducted study published by Huang (Huang et al, Clin Sci, 2002) used a similar protocol but had a 
cholesterol of $757 \mathrm{mg} / \mathrm{dl}$ in the control group. In this study, in spite of a marked rise of HDL-C, there was no arterial benefit. This, in my view, should have closed the story. Unfortunately it did not.

The probucol data, on the other hand, are definitely of high significance. Probucol raises CETP and prevents arterial disease (a number of reports have recently come from Japanese investigators e.g. Kasai et al. Atherosclerosis. 2012). Most excitingly, it removes cholesterol deposits (xanthelasmas/xanthomas) thus indicating that increased CETP is beneficial in man. Another negative issue to be raised is that in the Brusseau paper (ref 40 ) there was no evidence of a reduced cholesterol pool/increased fecal steroid excretion following torcetrapib, indicating again that blocking CETP does not in any way improve cholesterol turnover. I tend to believe that the issue of apo A-I syntheis is not of major significance. The reduction of AI synthesis (probucol) and increased synthesis (torcetrapib) is therefore of little interest.

In conclusion the author has certainly done a very good job but the paper would be improved by the inclusion of some older data, that in my view are more significant, vs data provided by the recent overviews or Mendelian randomizations.

Competing Interests: No competing interests were disclosed.

\section{I confirm that I have read this submission and believe that I have an appropriate level of expertise to confirm that it is of an acceptable scientific standard.}

Reviewer Report 17 July 2014

https://doi.org/10.5256/f1000research.4705.r5462

(c) 2014 Watts G. This is an open access peer review report distributed under the terms of the Creative Commons Attribution License, which permits unrestricted use, distribution, and reproduction in any medium, provided the original work is properly cited.

\section{Gerald F. Watts}

School of Medicine and Pharmacology, University of Western Australia, Crawley, WA, Australia

This is an exceptionally good review and balanced assessment of the status of CETP inhibitors and ASCVD from a world authority in the field. The article highlights important data that might have been overlooked when promulgating the clinical value of CETPIs and related trials.

Only 2 areas need revision:

1. Page 3, para 2: the notion that these data from Papp et al. convey is critical and the message needs an explicit sentence or two at end of paragraph.

2. Page 4, Conclusion: the assertion concerning the ethics of the two Phase 3 clinical trials needs toning down. Perhaps rephrase to indicate that the value and sense of doing these trials is open to question, with attendant ethical implications, or softer wording to that 
effect.

Competing Interests: No competing interests were disclosed.

I confirm that I have read this submission and believe that I have an appropriate level of expertise to confirm that it is of an acceptable scientific standard.

The benefits of publishing with F1000Research:

- Your article is published within days, with no editorial bias

- You can publish traditional articles, null/negative results, case reports, data notes and more

- The peer review process is transparent and collaborative

- Your article is indexed in PubMed after passing peer review

- Dedicated customer support at every stage

For pre-submission enquiries, contact research@f1000.com 